\title{
Enhancement of Biocontrol Activity of Cryptococcus laurentii by Silicon and the Possible Mechanisms Involved
}

\author{
Guo Z. Qin and Shi P. Tian
}

Key Laboratory of Photosynthesis and Environmental Molecular Physiology, Institute of Botany, Chinese Academy of Sciences, Xiangshan Nanxincun 20, Haidian District, Beijing 100093, China.

Accepted for publication 1 September 2004.

\section{ABSTRACT}

Qin, G. Z., and Tian, S. P. 2005. Enhancement of biocontrol activity of Cryptococcus laurentii by silicon and the possible mechanisms involved. Phytopathology 95:69-75.

Exogenous application of silicon $(\mathrm{Si})$ in the form of sodium metasilicate reduced disease development caused by Penicillium expansum and Monilinia fructicola in sweet cherry fruit at $20^{\circ} \mathrm{C}$. The inhibition of fruit decay was correlated closely with Si concentrations. Silicon at concentrations of $1 \%$, in combination with the biocontrol agent Cryptococcus laurentii at $1 \times 10^{7}$ cells per $\mathrm{ml}$, provided synergistic effects against both diseases. Population dynamics of C. laurentii were stimulated by $\mathrm{Si} 48 \mathrm{~h}$ after the yeast treatment in the wounds of sweet cherry fruit. Silicon strongly inhibited spore germination and germ tube elongation of $P$. expansum and M. fructicola in vitro. Based on results with scanning elec-

Penicillium expansum Link and Monilinia fructicola (G. Wint.) Honey cause serious fruit decay worldwide. Current disease management relies heavily on the use of synthetic chemical fungicides. However, concerns about public health and the development of resistant pathogens have increased the search for alternative methods (21). Heat treatment (24), UV-C light (25), biological control using microbial antagonists $(13,33,45)$, and substances generally regarded as safe $(14,17)$ have potential for control of fruit diseases. Biological control has proven useful for suppression of many plant diseases $(12,26,27,40)$. However, application of biocontrol agents alone often has not provided commercially acceptable control of plant diseases, but in combination with other strategies, the performance margin of biological controls was increased $(22,41,43)$.

Silicon ( $\mathrm{Si}$ ) is a major inorganic constituent of plants where the Si content ranges from 0.1 to $10.0 \%$ dry weight (18). Silicon application decreases the severity of plant diseases caused by fungal infections $(2,28,30,36)$. Chérif et al. (9) analyzed the effects of Si on cucumber plants and demonstrated that root decay and wilting caused by Pythium ultimum was reduced when cucumber plants were treated with potassium silicate. Efficacy of $\mathrm{Si}$ to reduce plant diseases is known especially in rice (11). Seebold et al. (38) reported that the application of Si fertilizers reduced the severity of blast, caused by Magnaporthe grisea, in irrigated and upland rice. Silicon is effective in reducing plant diseases of wheat (2), muskmelon (28), peach fruit (4), and pear fruit $(39,42)$. The mechanisms responsible for the protection of plants from fungal diseases by $\mathrm{Si}$ are not well understood. Silicon may act by

Corresponding author: S. P. Tian; E-mail address: tsp@ibcas.ac.cn

DOI: 10.1094/PHYTO-95-0069

(C) 2005 The American Phytopathological Society tron microscopy, growth of both pathogens was significantly inhibited by $\mathrm{Si}$ in the wounds of sweet cherry fruit. Compared with the wounded water control, Si treatment induced a significant increase in the activities of phenylalanine ammonia-lyase, polyphenoloxidase, and peroxidase in sweet cherry fruit but did not increase the levels of lignin. Application of $\mathrm{Si}$ activated a cytochemical reaction and caused tissue browning near the site of wounding. Based on our studies, the improvement in biocontrol efficacy of antagonistic yeast when combined with Si may be associated with the increased population density of antagonistic yeast by $\mathrm{Si}$, the direct fungitoxicity property of Si to the pathogens, and the elicitation of biochemical defense responses in fruit.

Additional keywords: blue mold, brown rot, induced resistance, mode of action. eliciting biochemical defense reactions, including the accumulation of lignin, phenolic compounds, and pathogenesis-related proteins in the infected plants $(9,19)$.

Synergistic effects for control of fruit decay were observed when biocontrol agents were combined with selected chemicals such as calcium chloride $(43,46)$, chitosan (15), 2-deoxy-D-glucose $(16,21)$, and salicylic acid (34). Little is known about the efficacy of Si on the activity of biocontrol agents. The objectives of this study were to (i) evaluate the effects of $\mathrm{Si}$, alone or in combination with a yeast biocontrol agent, Cryptococcus laurentii (Kufferath) Skinner, on control of the postharvest diseases blue mold and brown rot, caused by $P$. expansum and $M$. fructicola, respectively, in sweet cherry (Prunus avivum L. cv. Hongdeng) fruit; and (ii) determine the modes of action by which Si enhances the biocontrol efficacy of $C$. laurentii.

\section{MATERIALS AND METHODS}

Plant material. Sweet cherry (Prunus avivum cv. Hongdeng) fruit were harvested at commercial maturity and sorted by size and the absence of physical injuries or infections. The firmness of fruit was $13.7 \mathrm{~N}$ as determined by a penetrometer (FT-327, UC Fruit Firmness Tester, Milano, Italy), and soluble solids content was $18.7 \%$. Fruit were kept at $0^{\circ} \mathrm{C}$ and used within 3 days. Prior to use, fruit were disinfested with $2 \%$ (vol/vol) sodium hypochlorite for $2 \mathrm{~min}$, washed with tap water, and dried in air.

Yeast antagonist and pathogens. The yeast biocontrol agent, C. laurentii, was isolated from the surface of apple fruit following the method of Wilson and Chalutz (44) and identified by CABI Bioscience Identification Services (International Mycological Institute, UK). C. laurentii was cultured in 250-ml conical flasks containing $50 \mathrm{ml}$ of nutrient yeast dextrose broth $(8 \mathrm{~g}$ of nutrient broth, $5 \mathrm{~g}$ of yeast extract, and $10 \mathrm{~g}$ of dextrose in 1 liter of water) on a rotary shaker at $200 \mathrm{rpm}$ for $48 \mathrm{~h}$ at $25^{\circ} \mathrm{C}$. Yeast cells were 
centrifuged at $4,000 \times g$ for $10 \mathrm{~min}$, resuspended in sterile distilled water, and adjusted to a concentration of $1 \times 10^{7}$ cells per $\mathrm{ml}$ with a hemacytometer.

$P$. expansum and $M$. fructicola were isolated from infected sweet cherry fruit and maintained on potato dextrose agar (PDA) at $20^{\circ} \mathrm{C}$. The spores of both pathogens were removed from the surface of 2-week-old cultures and suspended in $5 \mathrm{ml}$ of sterile distilled water containing $0.05 \%$ ( $\mathrm{vol} / \mathrm{vol}$ ) Tween 80 . The suspensions were filtered through four layers of sterile cheesecloth to remove any adhering mycelia. Spore concentrations of $P$. expansum and $M$. fructicola were determined with a hemacytometer and adjusted to $1 \times 10^{4}$ spores per $\mathrm{ml}$ with sterile distilled water.

Effect of concentration of Si on fruit decay. Sweet cherries were wounded ( $3 \mathrm{~mm}$ deep by $3 \mathrm{~mm}$ wide) with a sterile nail at the equator of each fruit. Then, $15 \mu$ of a conidial suspension of $P$. expansum or $M$. fructicola, containing $1 \times 10^{4}$ spores per $\mathrm{ml}$, was placed on each wound. After $12 \mathrm{~h}, 20 \mu \mathrm{l}$ of Si in the form of sodium metasilicate (Sigma Chemical, St. Louis) was added to each wound, with individual fruit being treated with different concentrations $(0,0.2,0.4,0.6,0.8$, and $1 \%$ [wt/vol] $)$. Treated fruit were put in plastic boxes (200 by 130 by $50 \mathrm{~mm}$ ) with sterile water to maintain high humidity (about $95 \%$ ) and stored at $20^{\circ} \mathrm{C}$. Disease incidence and lesion diameter were measured after 3 days. There were three replicates of each treatment with 20 fruit per replicate, and the experiment was repeated twice.

Combined effect of Si and $C$. laurentii on fruit decay. In preliminary experiments, $C$. laurentii exhibited persistent protection of fruit from infection by pathogens but did not eradicate preexisting infections. In contrast, Si suppressed recently established infections but did not protect fruit from infection (data not
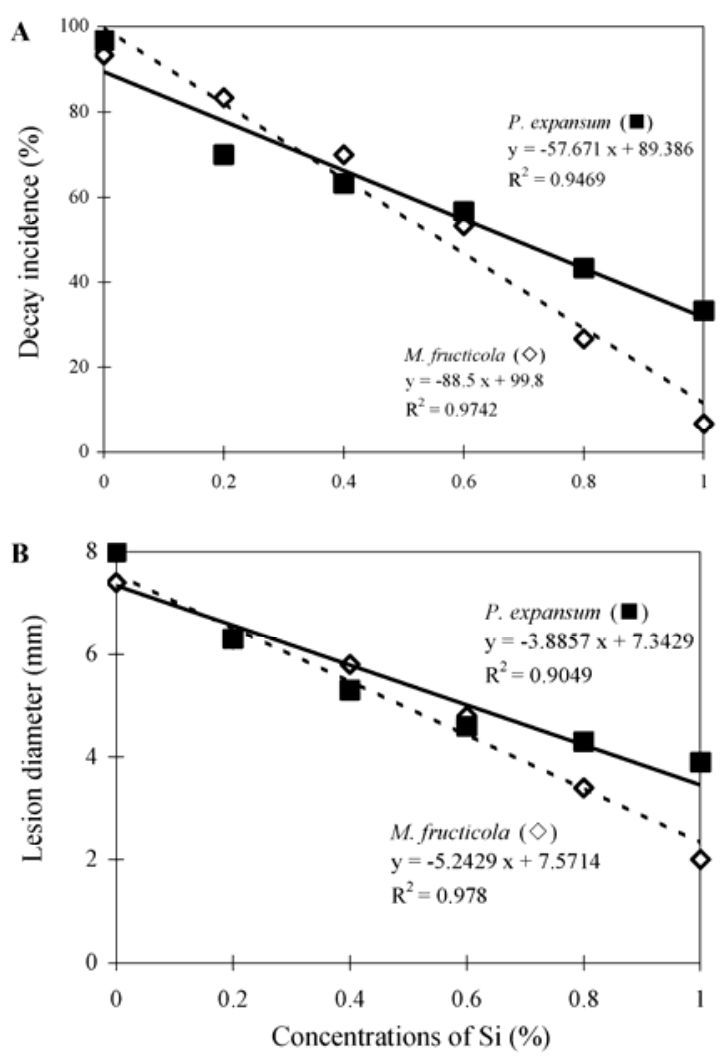

Fig. 1. Relationship of Si concentration with efficacy against Penicillium expansum and Monilinia fructicola of sweet cherry fruit at $20^{\circ} \mathrm{C}$. Fruit were wounded and inoculated with $P$. expansum or $M$. fructicola at $1 \times 10^{4}$ spores per ml. After $12 \mathrm{~h}$, each wound was treated with sterile distilled water or different concentrations of Si. A, Disease incidence and $\mathbf{B}$, lesion diameter were measured after 3 days. The data were based on three replicates of 20 fruit each, and the test was repeated twice with similar results. Values represent treatment means of pooled data. shown). In this experiment, $C$. laurentii was applied prior to treatment with Si to suppress diseases of sweet cherry fruit at $20^{\circ} \mathrm{C}$. Sweet cherries were wounded as described previously, and $20 \mu \mathrm{l}$ of a cell suspension of $C$. laurentii at $1 \times 10^{7}$ cells per ml or sterile distilled water was pipetted into each wound. Within $1 \mathrm{~h}$, each wound was inoculated with $15 \mu \mathrm{l}$ of a conidial suspension of $P$. expansum or $M$. fructicola at $1 \times 10^{4}$ spores per $\mathrm{ml}$. After $12 \mathrm{~h}$ of incubation, $20 \mu \mathrm{l}$ of $1 \%$ (wt/vol) sodium metasilicate was added to each wound. Wounds treated with water served as the control. Treated fruit were placed in plastic boxes ( 200 by 130 by $50 \mathrm{~mm}$ ) with sterile water to maintain high humidity (about 95\%) and stored at $20^{\circ} \mathrm{C}$. Disease incidence and lesion diameter were measured after 3, 4, and 5 days. There were three replicates of each treatment with 20 fruit per replicate, and the experiment was repeated twice.

Growth of $\boldsymbol{C}$. laurentii in wounds of sweet cherry fruit. Fruit were wounded, and $20 \mu \mathrm{l}$ of a cell suspension of $C$. laurentii at $1 \times 10^{7}$ cells per ml was added to each wound. After $12 \mathrm{~h}$, each wound was treated with $20 \mu \mathrm{l}$ of $1 \%$ (wt/vol) sodium metasilicate or sterile distilled water and stored at $20^{\circ} \mathrm{C}$ as described previously. Wound tissue was removed at $0,24,48,72$, and $96 \mathrm{~h}$ after treatment following the method of Janisiewicz et al. (23). The resulting cylinders of excised tissue $(10 \mathrm{~mm}$ deep by $10 \mathrm{~mm}$ wide) from five fruit were placed in a mortar with $10 \mathrm{ml}$ of sterile distilled water and ground with a pestle. Then, 100- $\mu$ l serial 10 -fold dilutions were plated on nutrient yeast dextrose agar medium. After incubation at $20^{\circ} \mathrm{C}$ for $72 \mathrm{~h}$, colonies were counted and expressed as $\log _{10} \mathrm{CFU}$ per wound. There were three replicates of each treatment, and the experiment was conducted three times.

Inhibition of growth of $P$. expansum and $M$. fructicola in vitro. The effects of $\mathrm{Si}$ on spore germination and germ tube elongation of $P$. expansum and $M$. fructicola were assayed in potato dextrose broth (PDB) according to the method of Tian et al. (43). Spore suspensions were prepared as described previously. Aliquots of $100 \mu \mathrm{l}$ of both pathogen suspensions were transferred to a glass tube (180 by $16 \mathrm{~mm}$ ) containing $5 \mathrm{ml}$ of PDB to obtain a final concentration of $5 \times 10^{5}$ spores per ml. The PDB contained various concentrations of sodium metasilicate $(0,0.2,0.4,0.6$, 0.8 , and $1 \%[\mathrm{wt} / \mathrm{vol}])$. All tubes were placed on a rotary shaker at $100 \mathrm{rpm}$ at $20^{\circ} \mathrm{C}$ and incubated for $15 \mathrm{~h}$. For each treatment, within each replicate, approximately 200 spores of each pathogen were observed to determine germination and germ tube length. Each treatment was replicated three times, and the experiment was repeated twice.

Scanning electron microscopy. For scanning electron microscopy, fruit were wounded and $15 \mu \mathrm{l}$ of a conidial suspension of $P$. expansum or $M$. fructicola at $1 \times 10^{5}$ spores per $\mathrm{ml}$ was placed on each wound. Within $1 \mathrm{~h}, 20 \mu \mathrm{l}$ of $1 \%$ (wt/vol) sodium metasilicate or sterile distilled water was added to each wound. Treated fruit were incubated at $20^{\circ} \mathrm{C}$ as described previously. Tissue samples were taken from the wounds 24 and $48 \mathrm{~h}$ after inoculation with $M$. fructicola and $P$. expansum, respectively. Samples were held overnight in fixative $(4 \%$ [vol/vol] formaldehyde and $1 \%$ [vol/vol] glutaraldehyde in $0.1 \mathrm{M}$ phosphate buffer, $\mathrm{pH}$ 7.2). Residual fixative was removed with repeated phosphate buffer washes. The samples were subsequently dehydrated in a series of ethanol solutions and then critical point dried with liquid $\mathrm{CO}_{2}$ in a desiccator. The specimens were mounted onto aluminum specimen stubs using conductive silver paint, sputter coated with gold, and observed with a scanning electron microscope (S-800, Hitachi Co., Tokyo) at $30 \mathrm{kV}$. Samples from five fruit from each treatment were used.

Induced biochemical reactions. For enzyme assay, sweet cherries were wounded, $20 \mu \mathrm{l}$ of $1 \%$ (wt/vol) sodium metasilicate was placed in each wound, and fruit were incubated at $20^{\circ} \mathrm{C}$ as described previously. Wounded fruit treated with water and nonwounded fruit served as controls. Samples containing the pericarp 
and flesh were taken from the wounds of 30 fruit at $0,6,12,24$, and $48 \mathrm{~h}$ after treatment. There were three replicates of each treatment, and the experiment was repeated twice.

For phenylalanine ammonia-lyase (PAL) assay, a 3-g tissue sample was homogenized with $30 \mathrm{ml}$ of $50 \mathrm{mM}$ sodium borate buffer ( $\mathrm{pH} 8.8$, containing $5 \mathrm{mM} \beta$-mercaptoethanol) and $0.5 \mathrm{~g}$ of polyvinyl pyrrolidone (PVP) and ground using a polytron tissue grinder (Kinematica CH-6010, Brinkman Co., Kriens-Luzern, Switzerland) at $4^{\circ} \mathrm{C}$. The mixture was centrifuged at $15,000 \times g$ for $30 \mathrm{~min}$ at $4^{\circ} \mathrm{C}$, and the supernatant was collected for enzyme analysis. The PAL activity was assayed following the method of Assis et al. (1) with some modification. One milliliter of enzyme extract was incubated with $2 \mathrm{ml}$ of borate buffer $(50 \mathrm{mM}, \mathrm{pH} 8.8)$ and $0.5 \mathrm{ml}$ of L-phenylalanine $(20 \mathrm{mM})$ for $60 \mathrm{~min}$ at $37^{\circ} \mathrm{C}$. The reaction was stopped with $0.1 \mathrm{ml}$ of $6 \mathrm{~N} \mathrm{HCl}$. The PAL activity was determined by the production of cinnamate, measured by the absorbance change at $290 \mathrm{~nm}$ with a spectrophotometer (UV-160, Shimadzu Corp., Kyoto, Japan). The blank was the crude enzyme preparation mixed with L-phenylalanine with zero time incubation. The protein content of the enzyme extracts was estimated by the method of Bradford (5). Specific enzyme activity was defined as nanomole cinnamic acid per hour per milligram of protein.

Polyphenoloxidase (PPO) and peroxidase (POD) were extracted according to the method of Chen et al. (8). Tissue samples ( $3 \mathrm{~g}$ ) of each treatment were homogenized with $30 \mathrm{ml}$ of $0.1 \mathrm{M}$ sodium phosphate buffer ( $\mathrm{pH}$ 6.4) containing $0.5 \mathrm{~g}$ of PVP and ground at $4^{\circ} \mathrm{C}$. The homogenate was centrifuged at $15,000 \times g$ for $30 \mathrm{~min}$ at $4^{\circ} \mathrm{C}$, and the supernatant was used for enzyme assays. The PPO activity was determined by adding $1 \mathrm{ml}$ of enzyme preparation to $2 \mathrm{ml}$ of catechol as a substrate, and the change was measured immediately in absorbance at $398 \mathrm{~nm}\left(A_{398}\right)$. The activity was expressed as $A_{398}$ per minute per milligram of protein.
The POD activity was determined using guaiacol as substrate (20). The reaction mixture consisted of $2 \mathrm{ml}$ of crude extract, $1 \mathrm{ml}$ of guaiacol, and $1 \mathrm{ml}$ of buffer. The reaction mixture was incubated at $30^{\circ} \mathrm{C}$ for $30 \mathrm{~min}$ before $1 \mathrm{ml}$ of $\mathrm{H}_{2} \mathrm{O}_{2}$ was added. Absorbance was measured at $460 \mathrm{~nm}\left(A_{460}\right)$. The activity of POD was defined as $A_{460}$ per minute per milligram of protein.

Lignin analysis. Fruit prepared for the lignin assay were treated as described previously for enzyme measurement. Lignin was detected quantitatively using a lignin thioglycolic acid (LTGA) method (6) with some modification. Samples were taken from the wounds of 30 fruit containing the pericarp and flesh at 0 , $6,12,24$, and $48 \mathrm{~h}$ after treatment. Samples $(10 \mathrm{~g})$ of each treatment were first extracted in two changes of $30 \mathrm{ml}$ of methanol over $24 \mathrm{~h}$; pellets were collected by centrifugation and transferred to glass beakers for drying $\left(24 \mathrm{~h}\right.$ at $\left.60^{\circ} \mathrm{C}\right)$. The resulting residue $(50 \mathrm{mg})$ was transferred to glass screw-cap tubes, and then $5 \mathrm{ml}$ of $2 \mathrm{~N} \mathrm{HCl}$ and $0.5 \mathrm{ml}$ of thioglycolic acid were added. The tubes were sealed and incubated in a water bath at $100^{\circ} \mathrm{C}$ for $4 \mathrm{~h}$ to hydrate the methanol insoluble residue. After cooling, the pellet was collected by centrifugation at $30,000 \times g$ for $10 \mathrm{~min}$ at $20^{\circ} \mathrm{C}$. The collected pellet was washed once with $5 \mathrm{ml}$ of distilled water. The resulting pellet was solubilized in $5 \mathrm{ml}$ of $0.5 \mathrm{~N} \mathrm{NaOH}$, sealed with Parafilm, and agitated gently at $20^{\circ} \mathrm{C}$ for $24 \mathrm{~h}$ to extract the lignin thioglycolate. Samples were centrifuged at 30,000 $\times$ $g$ for $10 \mathrm{~min}$ at $20^{\circ} \mathrm{C}$ and the supernatant solutions were transferred to glass centrifuge tubes. Then, $1 \mathrm{ml}$ of concentrated $\mathrm{HCl}$ was added to each tube and the tubes were stored at $4^{\circ} \mathrm{C}$ for $4 \mathrm{~h}$ to precipitate the LTGA. The precipitate was collected by centrifugation $(30,000 \times g, 10 \mathrm{~min})$ and washed once with $0.1 \mathrm{~N} \mathrm{HCl}$. The final pellet was dissolved in $10 \mathrm{ml}$ of $0.5 \mathrm{~N} \mathrm{NaOH}$, and the insoluble material was removed by centrifugation. The absorbance of the supernatant was measured at $280 \mathrm{~nm}$ with a spectro-
$\mathbf{A}$

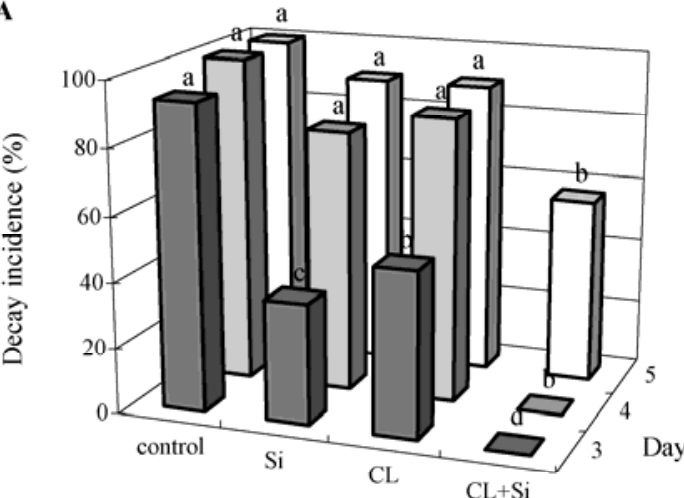

C

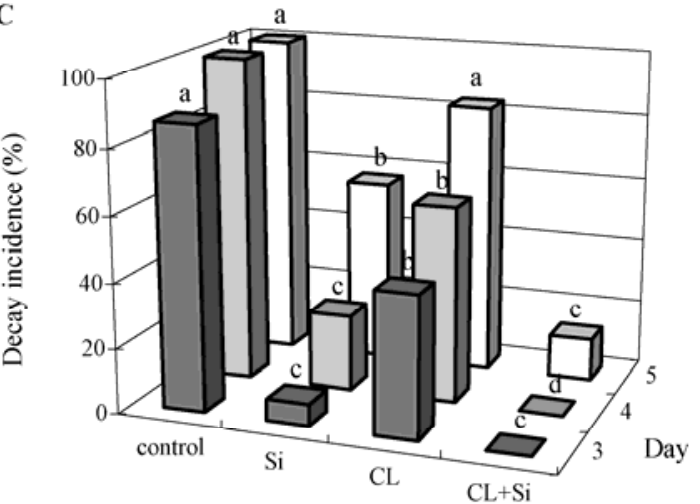

Treatment
$\mathbf{B}$

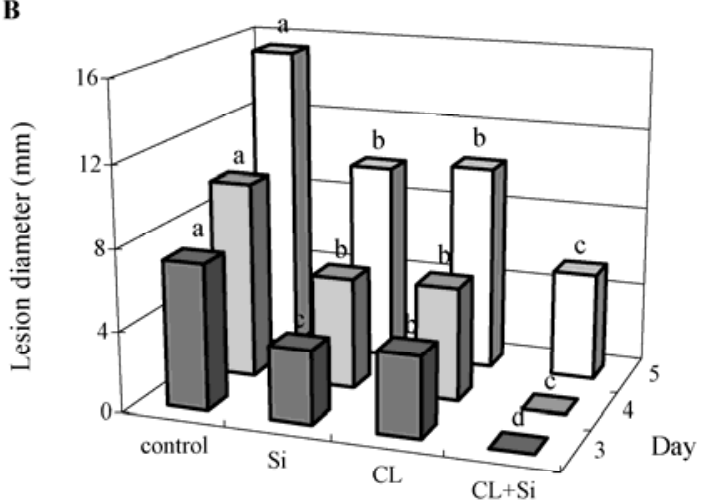

D

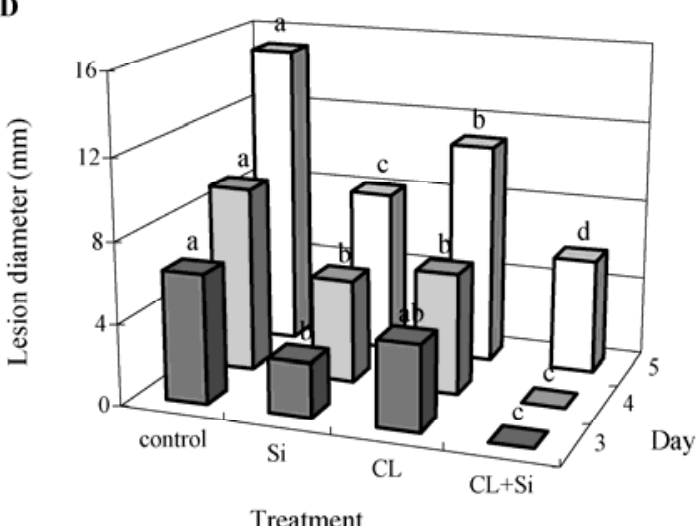

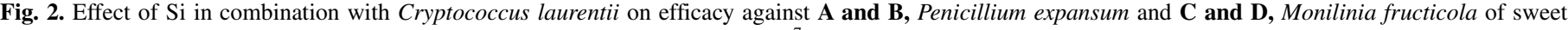

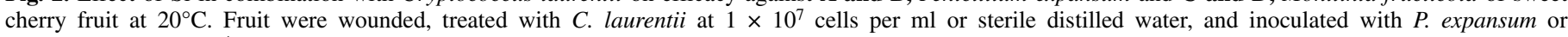

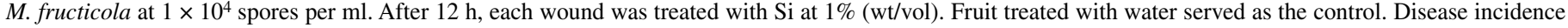

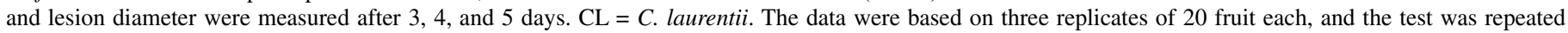
twice with similar results. Within each day, columns with the same letter are not statistically different according to the least significant difference test $(P<0.05)$. 
photometer (UV-160, Shimadzu). Results were expressed as $280 \mathrm{~nm}$ absorbance of LTGA in $10 \mathrm{ml}$ of $0.5 \mathrm{~N} \mathrm{NaOH}$. There were three replicates of each treatment, and the experiment was repeated twice.

Statistical analysis. Data for antagonist populations (CFU per wound) were transformed to logarithms to improve the homogeneity of variances. The incidence and severity of decay, population dynamics, and growth of pathogens in PDB were analyzed by analysis of variance with SPSS (SPSS Inc., Chicago, IL). When the treatment effects were statistically significantly $(P<0.05)$, the least significant difference test was used for means separation. Data analysis indicated that treatment effects were similar among the experimental repeats. Results presented were pooled across repeated experiments.

\section{RESULTS}

Effect of concentration of Si on fruit decay. The effectiveness of Si for controlling blue mold and brown rot in sweet cherry fruit was positively correlated with concentrations of Si (Fig. 1). At $0.6 \%(\mathrm{wt} / \mathrm{vol})$, Si significantly $(P<0.05)$ reduced decay incidence (Fig. 1A) and lesion diameter (Fig. 1B) of both diseases, while Si at $1 \%(\mathrm{wt} / \mathrm{vol})$ gave better disease control than $0.6 \%$ (wt/vol). After incubation at $20^{\circ} \mathrm{C}$ for 3 days, fruit treated with $\mathrm{Si}$ at $1 \%$ (wt/vol) had 63.4 and $86.6 \%$ less decay caused by blue mold and brown rot, respectively, than the water controls.

Combining Si with $C$. laurentii for control of fruit decay. Although a single application of $\mathrm{Si}$ reduced decay of blue mold and brown rot, better control was achieved when sweet cherry fruit were pretreated with $C$. laurentii (Fig. 2). The combination of $\mathrm{Si}$ and $C$. laurentii completely suppressed blue mold (Fig. 2A and $\mathrm{B}$ ) and brown rot (Fig. 2C and D) after 3 and 4 days of incubation at $20^{\circ} \mathrm{C}$. Disease incidence increased and lesion diameter enlarged as storage time increased. After incubation for 5 days, fruit treated with Si combined with C. laurentii had 43 and $87 \%$ less decay due to blue mold and brown rot, respectively, than the controls. Lesion diameters caused by both diseases also were reduced significantly $(P<0.05)$ by $\mathrm{Si}$ combined with $C$. laurentii.

Influence of Si on growth of $C$. laurentii in the wounds of sweet cherry fruit. Population dynamics of $C$. laurentii in the wounds of sweet cherry fruit were significantly influenced $(P<$ $0.05)$ by the application of Si $(1 \%$ [wt/vol] $)$ at $20^{\circ} \mathrm{C}$ (Fig. 3). The population density of $C$. laurentii was inhibited by $\mathrm{Si}$ during the first $48 \mathrm{~h}$ of the incubation period, but after that time, growth of yeast was stimulated. At the end of the study (96 h), the popu-

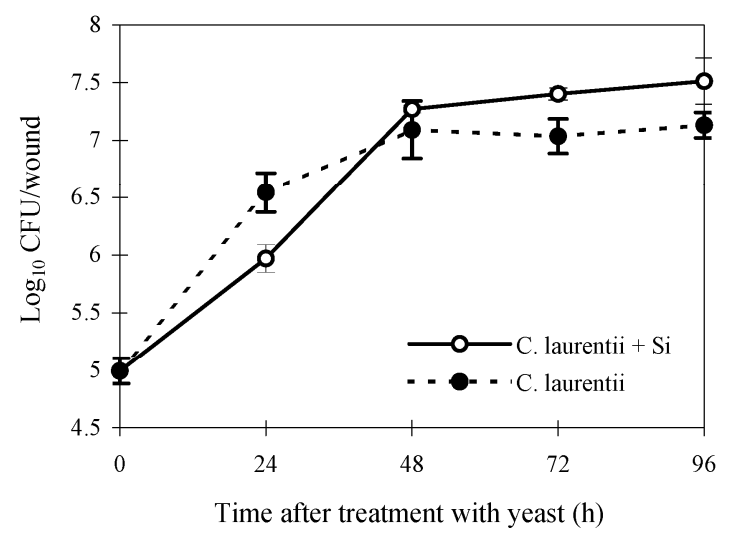

Fig. 3. Influence of $\mathrm{Si}$ on growth of Cryptococcus laurentii in the wounds of sweet cherry fruit. Fruit were wounded and treated with $C$. laurentii at $1 \times$ $10^{7}$ cells per ml. After $12 \mathrm{~h}$, each wound was treated with $1 \%$ (wt/vol) Si or sterile distilled water and stored at $20^{\circ} \mathrm{C}$. Colonies were expressed as $\log _{10}$ CFU per wound. The data were based on three replicates, and the test was conducted three times with similar results. Bars represent the standard deviation of the treatment mean of pooled data. lation density of $C$. laurentii in fruit treated with $\mathrm{Si}$ was almost 2.4-fold greater than that in the water-treated control.

Effect of Si concentration on growth of $P$. expansum and $M$. fructicola in vitro. Spore germination and germ tube elongation of $P$. expansum and $M$. fructicola pathogens were inhibited significantly $(P<0.05)$ by $\mathrm{Si}$ at $0.2 \%$ (wt/vol) (Fig. 4). Inhibition was positively correlated with Si concentration. At $0.6 \%$ (wt/vol), Si completely inhibited the growth of $P$. expansum and $M$. fructicola. Spore germination was less sensitive to Si than germ tube elongation.

Scanning electron microscopy observation. Inhibition of the growth of $P$. expansum and $M$. fructicola in the wounds of sweet cherry fruit by $\mathrm{Si}$ at $1 \%(\mathrm{wt} / \mathrm{vol})$ was investigated by scanning electron microscopy (Fig. 5). In Si-treated wounds, restricted mycelial growth was observed at $48 \mathrm{~h}$ for P. expansum (Fig. 5B) and at $24 \mathrm{~h}$ (Fig. 5D) for $M$. fructicola, whereas extensive mycelial ramification was evident in water-treated wound sites (Fig. $5 \mathrm{~A}$ and $\mathrm{C}$ ). Abnormal germ tubes, distorted mycelium, and swollen conidia of $P$. expansum were observed in wounds treated with $\mathrm{Si}$ (Fig. 5B). In contrast, normal spores and mycelial shapes were evident in the water-treated control fruit (Fig. 5A).

Induction of biochemical defense responses by Si treatment. Application of Si induced the accumulation of PAL, PPO, and POD in sweet cherry fruit (Fig. 6). Both wounding and Si treatment increased the activity of PAL, but the level in Si-treated fruit was higher than that in wounded control fruit (Fig. 6A). The PAL activity increased gradually and reached its highest value at $24 \mathrm{~h}$ in Si-treated fruit. The level was almost twofold greater than that in nonwounded control fruit at that time and was also significantly higher $(P<0.05)$ than that in wounded control fruit. Non-
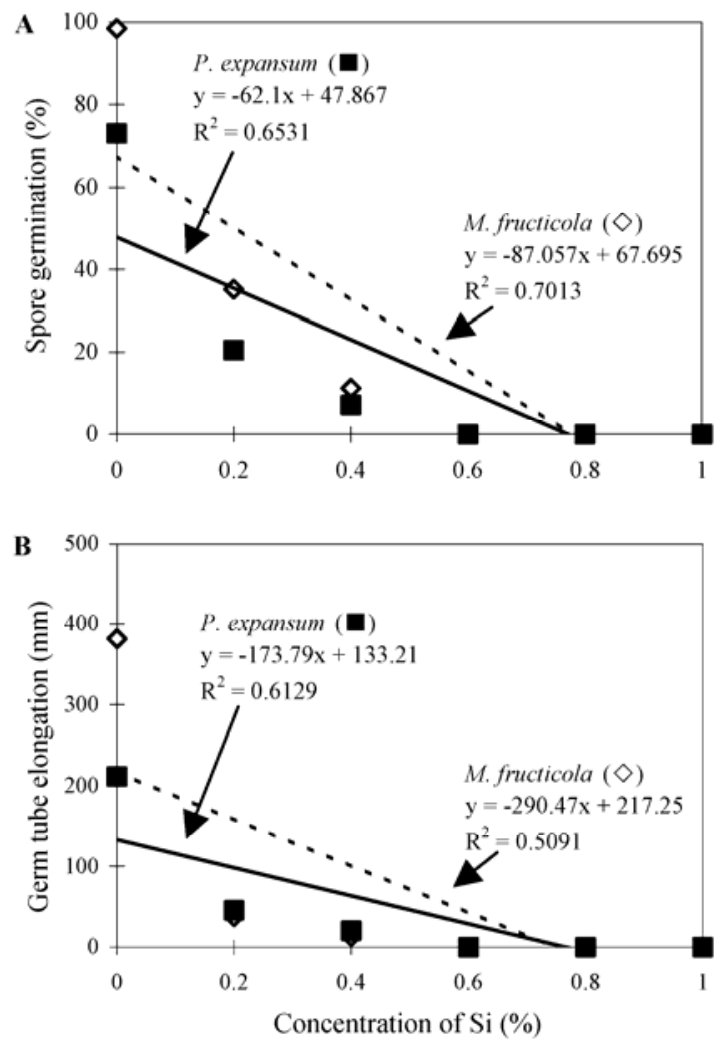

Fig. 4. Effect of Si on A, spore germination and $\mathbf{B}$, germ tube elongation of Penicillium expansum and Monilinia fructicola in vitro. Pathogen suspensions were incubated in potato dextrose broth containing different concentrations of $\mathrm{Si}$. Spore germination and germ tube elongation were observed after $15 \mathrm{~h}$ incubation on a rotary shaker at $100 \mathrm{rpm}$ at $20^{\circ} \mathrm{C}$. Approximately 200 spores of each pathogen were measured for germination rate and germ tube length per treatment within each replicate. Each treatment was replicated three times, and the experiment was repeated twice. 
wounded control fruit had a constant low level of PAL activity throughout the experiment.

Activity of PPO was stimulated by wounding. Adding Si to the wounds increased the accumulation of PPO in wounded fruit. In sweet cherry fruit treated with $\mathrm{Si}$, PPO increased quickly and reached the maximum level $12 \mathrm{~h}$ after treatment (Fig. 6B).

Application of Si resulted in a gradual increase of POD activity in sweet cherry fruit. The change in POD activity in wounded control fruit was similar to that in fruit treated with Si. However, the levels of POD activity were increased further by treatment with Si. Throughout the experiment, nonwounded control fruit maintained low levels of POD activity (Fig. 6C).

Browning of epidermal cells at the site of wounding was observed after Si treatment, whereas tissue browning was not evident in wounded control fruit.

Quantitative determination of lignin induced by $\mathrm{Si}$. Both wounding and $\mathrm{Si}$ induced the biosynthesis of lignin in sweet cherry fruit (Fig. 7). Lignin maintained high levels throughout the experiment in the wounded control and Si-treated fruit. The content of lignin in Si-treated fruit increased gradually and reached a maximum after $48 \mathrm{~h}$. Lignin accumulation in Si-treated fruit was not significantly $(P<0.05)$ greater than that in wounded control fruit during all stages of the 48 -h incubation period.

\section{DISCUSSION}

Silicon was effective in suppressing blue mold and brown rot caused by $P$. expansum and $M$. fructicola, respectively, in sweet cherry fruit, and efficacy was influenced by the concentration of
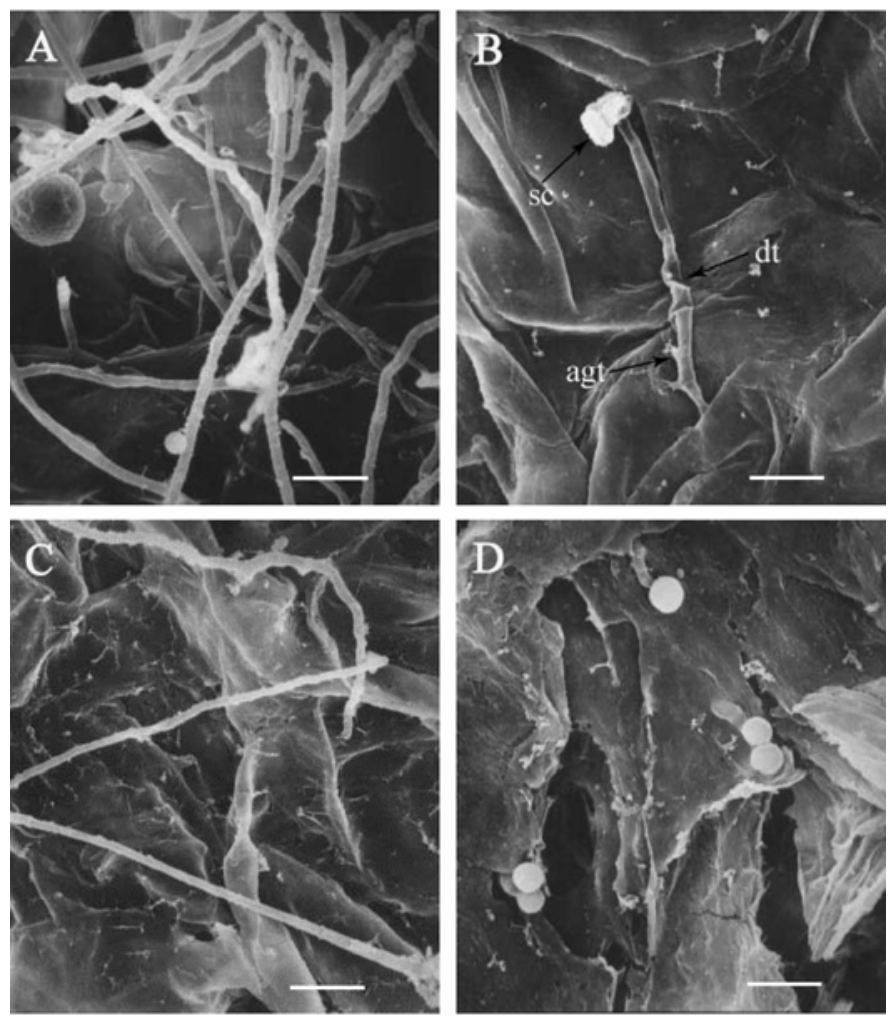

Fig. 5. Scanning electron micrographs of $\mathbf{A}$ and B, Penicillium expansum and $\mathbf{C}$ and D, Monilinia fructicola in the wounds of sweet cherry fruit. Fruit were wounded and inoculated with a conidial suspension of $P$. expansum or $M$. fructicola at $1 \times 10^{5}$ spores per $\mathrm{ml}$. Within $1 \mathrm{~h}$, each wound was treated with $\mathbf{B}$ and $\mathbf{D}, 1 \%$ (wt/vol) $\mathrm{Si}$ or $\mathbf{A}$ and $\mathbf{C}$, sterile distilled water and stored at $20^{\circ} \mathrm{C}$. Samples were removed from the wounds 24 and $48 \mathrm{~h}$ after M. fructicola and $P$. expansum inoculations, respectively. $\mathbf{A}$ and $\mathbf{B}, \mathbf{B a r}=15 \mu \mathrm{m}$; and $\mathbf{C}$ and $\mathbf{D}, \mathrm{Bar}=30 \mu \mathrm{m}$. agt = abnormal germ tube; $\mathrm{dt}=$ distorted mycelium; and $\mathrm{sc}=$ swollen conidia. Samples from five fruit of each treatment were examined.
Si. This result was consistent with the observation of Menzies et al. (29), who found that disease caused by Sphaerotheca fuliginea in cucumber plants was reduced significantly with increasing concentration of $\mathrm{Si}$ in nutrient solutions. Application of Si significantly improved the biocontrol ability of $C$. laurentii against blue mold and brown rot in sweet cherry fruit. Silicon, combined with C. laurentii, completely suppressed both diseases after 3 or 4 days of incubation at $20^{\circ} \mathrm{C}$. Combinations of biocontrol agents with safe chemicals, such as calcium chloride $(43,46)$, chitosan $(15)$, 2-deoxy-D-glucose $(16,21)$, and salicylic acid (34), are effective methods to enhance biological control activity. To our knowledge, this is the first report of a beneficial effect derived from the combination of $\mathrm{Si}$ and a biocontrol agent.

The mechanisms of $\mathrm{Si}$ enhancement of the biocontrol efficacy of $C$. laurentii appear to be complex. This may be associated with the effects of Si on the biocontrol agent, the pathogen, and sweet cherry fruit. In this study, the growth of $C$. laurentii in sweet
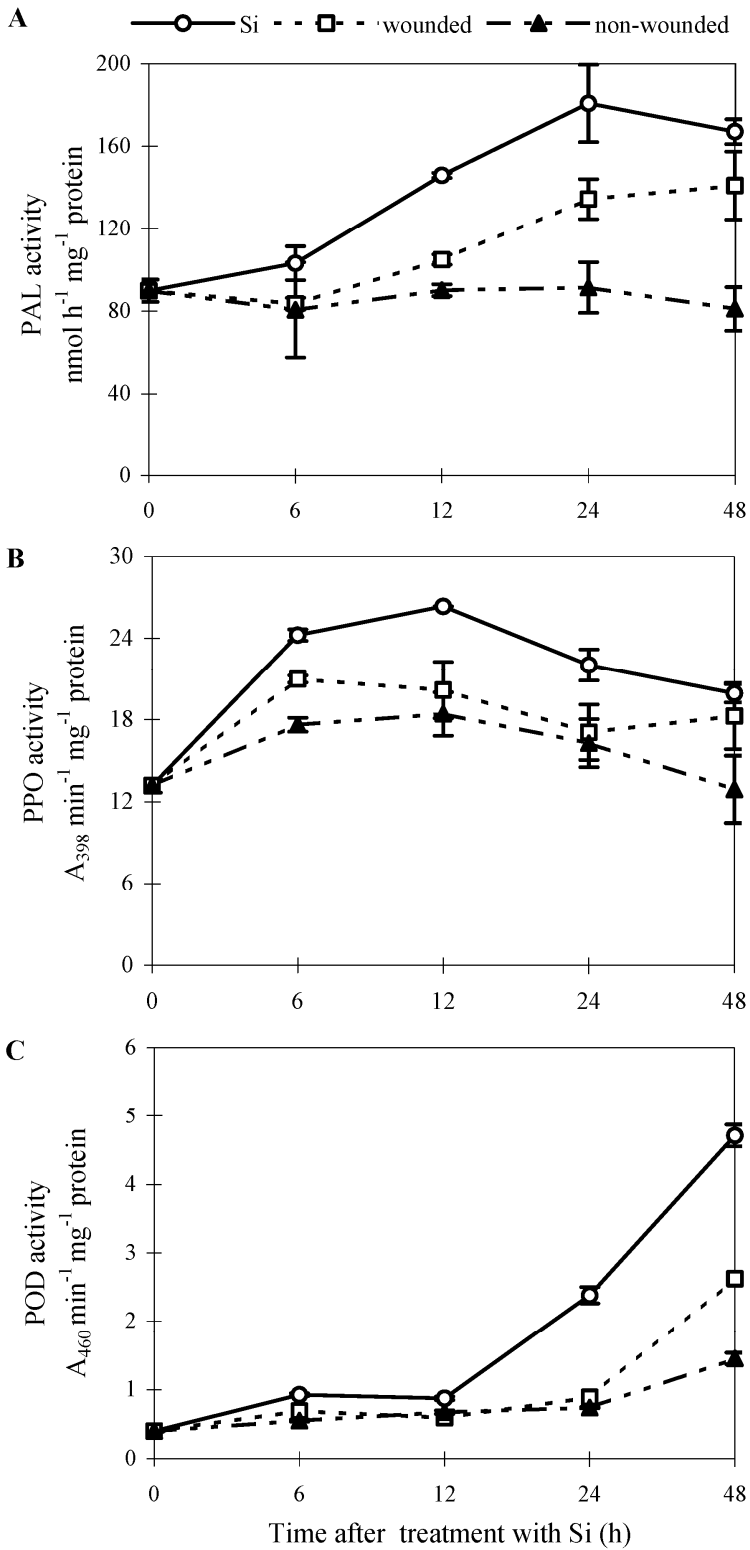

Fig. 6. Induction of A, phenylalanine ammonia-lyase (PAL), B, polyphenoloxidase (PPO), and $\mathbf{C}$, peroxidase (POD) activities by $\mathrm{Si}$ in sweet cherry fruit. Fruit were wounded, treated with $1 \%(\mathrm{wt} / \mathrm{vol}) \mathrm{Si}$, and stored at $20^{\circ} \mathrm{C}$. Fruit wounded and treated with water or nonwounded fruit served as controls. Each treatment contained three replicates, and the experiment was repeated twice with similar results. Bars represent the standard deviation of the treatment mean of pooled data. 


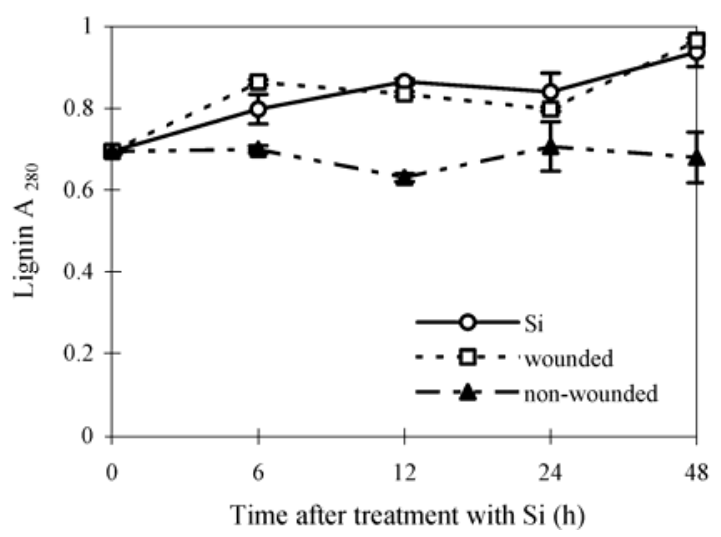

Fig. 7. Induction of lignin biosynthesis by $\mathrm{Si}$ in sweet cherry fruit. Fruit were wounded, treated with $1 \%(\mathrm{wt} / \mathrm{vol}) \mathrm{Si}$, and stored at $20^{\circ} \mathrm{C}$. Fruit wounded and treated with water or nonwounded fruit served as controls. Results were expressed as $280 \mathrm{~nm}$ absorbance of lignin thioglycolic acid in $10 \mathrm{ml}$ of $0.5 \mathrm{~N}$ $\mathrm{NaOH}$. Each treatment contained three replicates, and the experiment was repeated twice with similar results. Bars represent the standard deviation of the treatment mean of pooled data.

cherry fruit was stimulated by $\mathrm{Si} 48 \mathrm{~h}$ after incubation. Yeast antagonists often exert biocontrol activity through competition for nutrients and space (35). To control pathogens effectively, biocontrol agents must multiply more quickly than pathogens. Conversely, Si directly inhibited spore germination and germ tube elongation of $P$. expansum and $M$. fructicola in vitro in our study. Growth of both pathogens was inhibited completely when the concentration of Si was $0.6 \%$ (wt/vol). This result is similar to the observations of Biggs et al. (4), who found that calcium silicate could inhibit the growth of $M$. fructicola in vitro. Results of scanning electron microscopy observation of $P$. expansum and M. fructicola in the wounds of sweet cherry fruit confirmed that growth of the two pathogens was inhibited by Si treatment.

Plants defend themselves from pathogen infection through a wide variety of mechanisms (3). Resistance can be induced by abiotic and biotic inducers (37). Exogenous factors such as salicylic acid (31), $\beta$-aminobutyric acid (10), and benzothiadiazole (3) can lead to enhanced plant protection against various pathogens. In our study, Si induced biochemical defense reactions in sweet cherry fruit. Activities of PAL, PPO, and POD in fruit treated with Si were increased significantly compared with those in wounded or nonwounded control fruit. These three enzymes may combine to account for increased disease resistance. PAL is the first enzyme of the phenylpropanoid pathway and is involved in the biosyntheses of phenolics, phytoalexins, and lignins (32). The resulting phenolics could be oxidized by the action of PPO and POD to produce slightly colored compounds (i.e., quinines) (7). Quinines can polymerize to produce colored compounds typically seen in browning processes, which are highly toxic to invading microorganisms (7). Tissue browning of sweet cherry fruit around the site of wounding was observed after Si treatment. Lignin is thought to play a role in barricading the pathogen from invading the plant through physical exclusion (6). However, lignin content in Si-treated fruit was not significantly increased compared with that in wounded control fruit. It is likely that lignin deposition does not play as significant a role as accumulation of toxic materials in the defense response activated by $\mathrm{Si}$ in sweet cherry fruit.

\section{ACKNOWLEDGMENTS}

This work was supported by the National Science Fund for Distinguished Young Scholars of China (30225030) and the National Natural Science Foundation of China (30430480). We thank Y. Bi for good suggestions, and Y. S. Wang, H. J. Yao, Z. L. Chan, and B. Q. Li for technical assistance.

\section{LITERATURE CITED}

1. Assis, J. S., Maldonado, R., Muñoz, T., Escribano, M. I., and Merodio, C. 2001. Effect of high carbon dioxide concentration on PAL activity and phenolic contents in ripening cherimoya fruit. Postharvest Biol. Technol. 23:33-39.

2. Bélanger, R. R., Benhamou, N., and Menzies, J. G. 2003. Cytological evidence of an active role of silicon in wheat resistance to powdery mildew (Blumeria graminis f. sp. tritici). Phytopathology 93:402-412.

3. Benhamou, N., and Bélanger, R. R. 1998. Benzothiadiazole-mediated induced resistance to Fusarium oxysporum f. sp. radicis-lycopersici in tomato. Plant Physiol. 118:1203-1212.

4. Biggs, A. R., El-Kholi, M. M., El-Neshawy, S., and Nickerson, R. 1997. Effects of calcium salts on growth, polygalacturonase activity, and infection of peach fruit by Monilinia fructicola. Plant Dis. 81:399-403.

5. Bradford, M. M. 1976. A rapid and sensitive method for the quantitation of microgram quantities of protein utilizing the principle of protein-dye binding. Anal. Biochem. 72:248-254.

6. Bruce, R. J., and West, C. A. 1989. Elicitation of lignin biosynthesis and isoperoxidase activity by pectic fragments in suspension cultures of castor bean. Plant Physiol. 91:889-897.

7. Campos-Vargas, R., and Saltveit, M. E. 2002. Involvement of putative chemical wound signals in the induction of phenolic metabolism in wounded lettuce. Physiol. Plant. 114:73-84.

8. Chen, C., Bélanger, R., Benhamou, N., and Paulitz, T. C. 2000. Defense enzymes induced in cucumber roots by treatment with plant growthpromoting rhizobacteria (PGPR) and Pythium aphanidermatum. Physiol. Mol. Plant Pathol. 56:13-23.

9. Chérif, M., Benhamou, N., Menzies, J. G., and Bélanger, R. R. 1992. Silicon induced resistance in cucumber plants against Pythium ultimum. Physiol. Mol. Plant Pathol. 41:411-425.

10. Cohen, Y., Niderman, T., Mösinger, E., and Fluhr, R. 1994. $\beta$-Aminobutyric acid induces the accumulation of pathogenesis-related proteins in tomato (Lycopersicon esculentum L.) plants and resistance to late blight infection caused by Phytophthora infestans. Plant Physiol. 104:59-66.

11. Datnoff, L. E., Deren, C. W., and Snyder, G. H. 1997. Silicon fertilization for disease management of rice in Florida. Crop Prot. 16:525-531.

12. Droby, S., Cohen, L., Daus, A., Weiss, B., Horev, B., Chalutz, E., Kate, H., Keren-Tzur, M., and Shachnai, A. 1998. Commercial testing of Aspire: A yeast preparation for the biological control of postharvest decay of citrus. Biol. Control 12:97-101.

13. Droby, S., Vinokur, V., Weiss, B., Cohen, L., Daus, A., Goldschmidt, E. E., and Porat, R. 2002. Induction of resistance to Penicillium digitatum in grapefruit by the yeast biocontrol agent Candida oleophila. Phytopathology 92:393-399.

14. El-Ghaouth, A., Arul, J., Grenier, J., and Asselin, A. 1992. Antifungal activity of chitosan on two postharvest pathogens of strawberry fruits. Phytopathology 82:398-402.

15. El-Ghaouth, A., Smilanick, J. L., Brown, G. E., Ippolito, A., Wisniewski, M., and Wilson, C. L. 2000. Applications of Candida saitoana and glycolchitosan for the control of postharvest diseases of apple and citrus fruit under semi-commercial conditions. Plant Dis. 84:243-248.

16. El-Ghaouth, A., Smilanick, J. L., Wisniewski, M., and Wilson, C. L. 2000. Improved control of apple and citrus fruit decay with a combination of Candida saitoana and 2-deoxy-D-glucose. Plant Dis. 84:249-253.

17. El-Ghaouth, A., Wilson, C. L., and Wisniewski, M. 1997. Antifungal activity of 2-deoxy-D-glucose on Botrytis cinerea, Penicillium expansum, and Rhizopus stolonifer: Ultrastructural and cytochemical aspects. Phytopathology 87:772-779.

18. Epstein, E. 1994. The anomaly of silicon in plant biology. Proc. Natl. Acad. Sci. USA 91:11-17.

19. Epstein, E. 1999. Silicon. Annu. Rev. Plant Physiol. Plant Mol. Biol. 50:641-664.

20. Ippolito, A., El-Ghaouth, A., Wilson, C. L., and Wisniewski, M. 2000. Control of postharvest decay of apple fruit by Aureobasidium pullulans and induction of defense responses. Postharvest Biol. Technol. 19:265-272.

21. Janisiewicz, W. J. 1994. Enhancement of biocontrol of blue mold with the nutrient analog 2-deoxy-D-glucose on apples and pears. Appl. Environ. Microbiol. 60:2671-2676.

22. Janisiewicz, W. J., and Korsten, L. 2002. Biological control of postharvest diseases of fruits. Annu. Rev. Phytopathol. 40:411-441.

23. Janisiewicz, W. J., Usall, J., and Bors, B. 1992. Nutritional enhancement of biocontrol of blue mold on apples. Phytopathology 82:1364-1370.

24. Kim, J. J., Ben-Yehoshua, S., Shapiro, B., Henis, Y., and Carmeli, S. 1991. Accumulation of scoparone in heat-treated lemon fruit inoculated with Penicillium digitatum Sacc. Plant Physiol. 97:880-885.

25. Lamikanra, O., Richard, O. A., and Parker, A. 2002. Ultraviolet induced stress response in fresh cut cantaloupe. Phytochemistry 60:27-32.

26. Leverentz, B., Conway, W. S., Camp, M. J., Janisiewicz, W. J., Abuladze, T., Yang, M., Saftner, R., and Sulakvelidze, A. 2003. Biocontrol of Lis- 
teria monocytogenes on fresh-cut produce by treatment with lytic bacteriophages and a bacteriocin. Appl. Environ. Microbiol. 69:4519-4526.

27. McLaughlin, R. J., Wilson, C. L., Chalutz, E., Kurtzman, C. P., Fett, W. F., and Osman, S. F. 1990. Characterization and reclassification of yeast used for biological control of postharvest diseases of fruits and vegetables. Appl. Environ. Microbiol. 56:3583-3586.

28. Menzies, J., Bowen, P., Ehret, D., and Glass, A. D. M. 1992. Foliar applications of potassium silicate reduce severity of powdery mildew on cucumber, muskmelon, and zucchini squash. J. Am. Soc. Hortic. Sci. 117:902-905.

29. Menzies, J. G., Ehret, D. L., Glass, A. D. M., Helmer, T., Koch, C., and Seywerd, F. 1991. Effects of soluble silicon on the parasitic fitness of Sphaerotheca fuliginea on Cucumis sativus. Phytopathology 81:84-88.

30. Menzies, J. G., Ehret, D. L., Glass, A. D. M., and Samuels, A. L. 1991. The influence of silicon on cytological interactions between Sphaerotheca fuliginea and Cucumis sativus. Physiol. Mol. Plant Pathol. 39:403-414.

31. Murphy, A. M., Holcombe, L. J., and Carr, J. P. 2000. Characteristics of salicylic acid-induced delay in disease caused by a necrotrophic fungal pathogen in tobacco. Physiol. Mol. Plant Pathol. 57:47-54.

32. Pellegrini, L., Rohfritsch, O., Fritig, B., and Legrand, M. 1994. Phenylalanine ammonia-lyase in tobacco. Plant Physiol. 106:877-886.

33. Qin, G. Z., Tian, S. P., and Xu, Y. 2004. Biocontrol of postharvest diseases on sweet cherries by four antagonistic yeasts in different storage conditions. Postharvest Biol. Technol. 31:51-58.

34. Qin, G. Z., Tian, S. P., Xu, Y., and Wan, Y. K. 2003. Enhancement of biocontrol efficacy of antagonistic yeasts by salicylic acid in sweet cherry fruit. Physiol. Mol. Plant Pathol. 62:147-154.

35. Roberts, R. G. 1990. Postharvest biological control of gray mold of apple by Cryptococcus laurentii. Phytopathology 80:526-530.

36. Rodrigues, F. Á., Vale, F. X. R., Datnoff, L. E., Prabhu, A. S., and Korndörfer, G. H. 2003. Effect of rice growth stages and silicon on sheath blight development. Phytopathology 93:256-261.

37. Schneider, S., and Ullrich, W. R. 1994. Differential induction of resis- tance and enhanced enzyme activities in cucumber and tobacco caused by treatment with various abiotic and biotic inducers. Physiol. Mol. Plant Pathol. 45:291-304.

38. Seebold, W., Kucharek, T. A., Datnoff, L. E., Correa-Victoria, F. J., and Marchetti, M. A. 2001. The influence of silicon on components of resistance to blast in susceptible, partially resistant, and resistant cultivars of rice. Phytopathology 91:63-69.

39. Spotts, R. A., and Cervantes, L. A. 1989. Evaluation of disinfestant-flotation salt-surfactant combinations on decay fungi of pear in a model dump tank. Phytopathology 79:121-126.

40. Spotts, R. A., Cervantes, L. A., and Facteau, T. J. 2002. Integrated control of brown rot of sweet cherry fruit with a preharvest fungicide, a postharvest yeast, modified atmosphere packaging, and cold storage temperature. Postharvest Biol. Technol. 24:251-257.

41. Spotts, R. A., Cervantes, L. A., Facteau, T. J., and Chand-Goyal, T. 2002. Control of brown rot and blue mold of sweet cherry with preharvest iprodione, postharvest Cryptococcus infirmominiatus, and modified atmosphere packaging. Plant Dis. 82:1158-1160.

42. Sugar, D., and Spotts, R. A. 1986. Effect of flotation salt solutions on spore germination of four decay fungi and on side rot of pear. Plant Dis. 70:1110-1112.

43. Tian, S. P., Fan, Q., Xu, Y., and Jian, A. L. 2002. Effects of calcium on biocontrol activity of yeast antagonists against the postharvest fungal pathogen Rhizopus stolonifer. Plant Pathol. 51:352-358.

44. Wilson, C. L., and Chalutz, E. 1989. Postharvest biological control of Penicillium rots of citrus with antagonistic yeasts and bacteria. Sci. Hortic. 40:105-112.

45. Wilson, C. L., and Wisniewski, M. E. 1989. Biological control of postharvest diseases of fruits and vegetables: An emerging technology. Annu. Rev. Phytopathol. 27:425-441.

46. Wisniewski, M., Droby, S., Chalutz, E., and Eilam, Y. 1995. Effects of $\mathrm{Ca}^{2+}$ and $\mathrm{Mg}^{2+}$ on Botrytis cinerea and Penicillium expansum in vitro and on the biocontrol activity of Candida oleophila. Plant Pathol. 44:1016-1024. 